\title{
Polls and elections: Is Loyalty a Powerful Thing? Republican Senate Campaign Strategy and Trump Coattails in the 2016 Election
}

Neilan S. Chaturvedi

Chris Haynes

Follow this and additional works at: https://digitalcommons.newhaven.edu/politicalsciencefacpubs

Part of the Political Science Commons

\section{Comments}

This is the peer reviewed version of the following article: Chaturvedi, N.S. \& Haynes, C. (2019) Polls and elections: Is Loyalty a Powerful Thing? Republican Senate campaign strategy and Trump coattails in the 2016 election. Presidential Studies Quarterly Volume 49, Issue 2, pp. 432-448, which has been published in final form at https://doi.org/10.1111/psq.12523

This article may be used for non-commercial purposes in accordance with Wiley Terms and Conditions for Use of Self-Archived Versions." 


\title{
Is Loyalty a Powerful Thing? Republican Senate Campaign Strategy and Trump Coattails in the 2016 Election
}

\author{
Neilan S. Chaturvedi \\ Assistant Professor of Political Science \\ California State Polytechnic University, Pomona
}

\author{
Chris Haynes \\ Assistant Professor of Political Science \\ University of New Haven
}


The presidential election of 2016 proved to be a challenging one for Republican candidates. At the top of their ticket was Donald J. Trump, a polarizing presidential candidate whose popularity with his base was only rivaled by his unpopularity with his opposition. Trump was quickly known for his divisive rhetoric on race, policy, and foreign relations. His rhetoric grew so problematic, that candidates running for other offices faced a difficult decision in which Trump forced many Republicans to think long and hard about the extent to which they embrace, eschew, or remain ambiguous with respect to their party's standard holder.

Comparing Trump to his predecessor, anecdotal evidence from 2008 suggests that presidential coattails for newly elected presidents are indeed real. After all, the case could be made that then-Senator Obama helped elect eight new senators. Scholarly work also legitimizes the idea of presidential coattails. In their seminal work examining presidential coattails and their effect on Senate elections, Campbell and Sumners (1990) find that between 1972 and 1988, presidential coattails have a modest effect on Senate elections in which a ten-percentage-point gain in a party's presidential vote in the state adds approximately two percent to the Senate candidate's vote total. The logic here, of course, is that popular presidential candidates turn out voters who are likely to vote for the candidate's co-partisans down the ballot (Stewart 1987).

Still, Trump presents a unique situation. An unconventional Republican, Trump was not well liked by much of the Republican establishment. As such, the logic of a popular presidential candidate turning out voters does not necessarily apply—or at the very least, candidates cannot rely on this as a means to reelection. That is to say, given his unpredictable campaign, Republican Senate candidates were likely pessimistic about their outlook towards Trump's coattails. So what is the optimal strategy for the Republican Senate candidate? 
In this article, we argue that state politics determines the optimal strategy for candidates who are saddled with a controversial presidential candidate. Indeed, based on our findings, voters reward candidates at varying levels for taking these positions. Specifically, the disloyal strategy worked best in swing states and amongst Democrats, liberals, and Clinton voters. The ambiguous strategy was less effective, but still received gains in appeal amongst independents and liberals.

While previous research examines the effects of candidate issue position taking, the effects of position-taking vis-à-vis presidential standard bearers, common in this digital and media age, is unknown. We then draw on previous work in social psychology to develop our hypothesis on candidate position-taking vis-à-vis co-partisan presidential candidates. Using a series of survey experiments to test the effects of candidate position-taking vis-à-vis Republican presidential nominee Donald Trump in the run-up to the 2016 campaign, we find that the least optimal strategy is to be disloyal or take a position against one's presidential nominee. Moreover, we find that while being ambiguous may help in certain contexts, our survey data suggests that the optimal strategy is to remain loyal until the end. We end by discussing our implications and avenues for future research.

\section{Presidential Coattails and Strategy on Presidential Candidates}

The scholarly literature on candidate positioning suggests that there is logic and perhaps an optimal strategy for Republican candidates in this situation. For example, Tomz and Van Houweling (2008) find that voters often vote based on the candidate's ideological proximity to them and as such, candidates have an incentive to position themselves closest to their constituents' feelings towards the candidate. Indeed, if a voter examines a candidate based on their position on Trump, it could serve as a proxy for the candidate's ideological placement. As 
such, senators representing blue states should position themselves in a disloyal way so as to appear to reject Trump while red state senators should embrace him and appear loyal to the presidential nominee. Still, what happens when states lack a clear opinion on the president, a la swing states? Bishin (2008) argues that rather than focusing on the median voter, legislators should focus on the most active sub-constituency as it relates to partisanship. For example, if the base is lukewarm to Trump but there is an active and vocal sub-constituency that opposes Trump, the senator should choose to oppose Trump.

Even still, there remains an option beyond the cut and dry options of opposing or embracing Trump: offering only ambiguous positions. This option is not without its benefits. Voters may view the ambiguity through the lens of their own biases and assume that the ambiguous candidate sides with them (Irwin 1953; Krosnick 2002; Rosenhan and Messick 1996; Tomz and Van Howeling 2009). Still, others find that ambiguity may lead voters to believe that the candidate is "evasive or spineless" (Campbell 1983). Furthermore, even disloyalty to the party's presidential candidate can come with costs. Indeed, while disloyalty may appease angry opposition voters, it does little to excite the base of voters that are supportive of the president and may even go as far as to turn them off of the candidate. We seek to shed light the discrepancy on the optimal strategy in this unique case in which Republican Senate candidates were forced to take a position on their party's controversial presidential candidate.

\section{Data and Methods}

To examine which strategy, loyalty, ambiguity, or disloyalty, plays best for Senate candidates, we conducted an original online Mechanical Turk survey experiment in the Summer of 2016. The experiment used participants recruited through Amazon's Mechanical Turk service and 
referred to our Qualtrics based survey instrument. We restricted participants to those only with U.S. IP addresses. Participants received $\$ .50$ to take the survey which lasted, on average 8-10 minutes. In total, we recruited 1,373 participants. ${ }^{1}$

Participants were randomly assigned to receive one of three visual positioning prompts. The first group was shown a Republican candidate embracing Trump (i.e. the "loyal candidate" treatment) opposed by a standard Democratic candidate opposing Trump $(\mathrm{N}=423)$. The second group was shown a Republican candidate taking an ambiguous position on Trump (i.e. the “ambiguous candidate" treatment) opposed by a standard Democratic candidate who opposed Trump (N=483). Finally, the third group was shown a Republican candidate taking a position against Trump (i.e. the "disloyal candidate" treatment) opposed by a standard Democrat (467). Appendix A illustrates the images that were shown to each group. ${ }^{2}$

Each participant in each group was then asked the same questions measuring candidate preference, affect, and excitement. To measure candidate preference, participants were asked, "Which candidate do you prefer?" (the options were the Democratic Candidate or the Republican candidate). Candidate preference helps us identify how voters might use proximity to gauge each candidate, though it is difficult to see voters changing their candidate preference simply based on one heuristic. As a result, we also ask participants to answer the following question to measure candidate affect:

Based on this information, we would like you to rate your feelings towards the candidates using a scale that we call a feeling thermometer. Ratings between 0-50 indicate that you don't feel favorable toward the person and that you don't care too much for that person. Ratings between 50-100 indicate that you feel warm towards the person and are favorable toward them. You would rate them at 50 if you don't feel particularly cool or warm.

\footnotetext{
${ }^{1}$ We note that the use of the Mechanical Turk service to recruit survey experiment participants has come under some scrutiny. Still, Berinsky et al. (2012) find that these participants are often more representative of the overall population than other means of recruiting participants (i.e. the use of college students, etc.).

${ }^{2}$ We performed manipulation checks by asking participants to separately identify the positions of each candidate vis-à-vis Donald Trump. We only present the data for participants who successfully received the manipulation.
} 
Participants were then presented with a horizontal scale ranging from zero to one hundred in which they pulled a vertical bar to indicate their answer.

Lastly, we measure a key aspect of winning elections - turnout. To measure this, we ask participants who excited they are to turn out to vote for the Republican. Specifically, they were asked, "On a scale from one to ten, where one means that you are not excited at all and ten means that you are very excited, how excited are you to vote for the Republican?"

We also asked participants to provide responses to a number of socio-political demographic questions. Table 1 illustrates the composition for each treatment group.

[Insert Table 1 here]

Each group has an approximately equal number of participants and the randomization process has evenly distributed participants to each group based on these demographics.

Based on the literature on the topic, we suspect that the three strategies will yield little significant effect on the participants' candidate preference. After all, this is just one heuristic that voters may use in determining their vote choice. Furthermore, the proximity hypothesis argues that voters prefer candidates that are closest to their ideological point and as such, we expect that Democrats will not be strongly swayed to the disloyal or ambiguous Republicans (Tomz and Van Houweling 2008).

Still, given our more malleable measures such as candidate affect and excitement, we may expect to see significant shifts in opinions. If the proximity thesis is correct, we might expect voters that largely disapprove of a president to favor a senate candidate that likewise disapproves of the president, the disloyal strategy. Thus, we might expect Democrats, independents, liberals, and moderates who are more likely to disapprove of Trump to report "warmer" thermometer scores for the disloyal Republican senate candidate. Conversely, we 
might expect Republicans to feel "colder" toward disloyal Republican candidates. Yet still we might find that the ambiguous position may appeal to a variety of voters as Krosnick (2002) finds that voters place their own biases upon ambiguous candidates, making them more appealing (though Campbell (1983) finds that this strategy can also backfire).

To test these expectations, we examine how participants react to the treatments based on their ideology, partisanship, and the type of state that the participants reside in. For ideology, we asked participants to rate whether they are liberal, conservative, or moderate. We did clarify if the moderates had an ideological lean, and as such, we code moderates as those that self identified as truly moderate without an ideological bias. For partisanship, we examine Democrats, Republicans, and Independents. For independents, we again only count those with no partisan bias. Finally, we examine participants by the type of state they reside in: blue states, red states, and swing states. We operationalize the type of state to include blue states, or states that have consistently voted for the Democratic candidate over the last three election cycles prior to 2016, red states, and swing states, or states that have voted for more than one of the two parties over the last three election cycles, or where both parties have been competitive in (e.g. invested resources in). See Appendix A for a full typology of states. In the following section, we examine this in greater detail.

\section{Results}

We present the results in six tables summarizing the results of T-tests analyzing the differences in means between the "loyal" or control group, and the two treatment groups (ambiguous and disloyal, respectively). Specifically, we look at the results by the participant's partisanship, ideology, the type of state that they reside in, and their 2016 presidential vote choice. We should note that their vote choice is based the participant's answer which was asked prior to the 
election. It should also be noted that the question was asked before both the James Comey memo against Hillary Clinton as well as the Access Hollywood tapes recording Donald Trump. Table 2 presents the results of the T-tests examining the participants' preferences for the Democrat and Republican for the loyal and ambiguous experiment groups. Note that the values represent the total percent of participants preferring the Republican candidate in each group.

[Insert Table 2 here]

In terms of party identification, the only group that was significantly different between the loyal and ambiguous groups was independents, in which the independents in the ambiguous group preferred the ambiguous Republican more than the independents in the loyal group preferred the loyal Republican. With regards to ideology, liberals in the ambiguous group preferred the Republican marginally more than liberals in the loyal group. Similarly, red state voters in the ambiguous group preferred the Republican candidate at a higher rate than red state voters in the loyal group. Finally, voters who identified themselves as Trump voters had a higher preference for the Republican candidate in the ambiguous group than in the loyal group, though again, the difference is marginal and the preference for the Republican in both groups was relatively high (87.63 and 95.97 percent, respectively).

These results suggest that the ambiguous strategy did little to affect voter preference as only independents were significantly moved to vote for the Republican when exposed to that strategy. While liberals in the ambiguous treatment did prefer the Republican candidate to liberals in the loyal treatment, the change was marginal at best, and likely reflects a very small shift in vote choice. ${ }^{3}$ Perhaps most importantly, there are no drawbacks to using this strategy.

\footnotetext{
${ }^{3}$ We did attempt to see what is driving these results by examining interactions between these terms (i.e. Democrats in red states) but given our limitations with regards to the number of
} 
That is, Republicans can choose the ambiguous path with no retribution from voters, including those that are key to their electoral coalitions. Furthermore, among voters who are already inclined to vote for the Republican, specifically red state voters and trump voters, the ambiguous strategy has positive effects on candidate preference.

Table 3 presents the difference in means between participants in the loyal group and participants in the disloyal group. Again, the values represent the total percent of participants preferring the Republican candidate in each group.

\section{[Insert Table 3 here]}

In terms of the partisanship and ideology of the participant, there were no significant differences between the participants of the loyal and disloyal groups. The only difference was for participants in swing states in which participants in the disloyal group preferred the Republican more than their counterparts in the loyal group. This is interesting as there is little to identify in terms of the individual characteristics driving these opinions. That is to say, swing state voters are unique and prefer the disloyal Republican. Finally, again, Trump voters in the disloyal group preferred the Republican candidate at a slightly higher rate than Trump voters in the loyal group.

Looking more specifically at voters within each type of state, we find some nuance for what is driving the differences in swing states, though, we are limited by the smaller number of observations in these cells. Specifically, we see that in swing states, the higher preferences for the disloyal Republican are being driven by independents, Republicans, and conservatives.

In sum, it seems that positioning vis-à-vis Trump made little difference as to how participants viewed their preference for voting for the two hypothetical candidates. Any changes were marginal at best, though two notable findings stand out. First, independents and red state

observations in each cell, we were unable to identify further what is driving these results. We do, however, report the results in the appendix. 
voters preferred the ambiguous Republican at a higher rate than independents and red state voters preferred the loyal Republican. There were no notable findings for the differences between the loyal and disloyal Republican except that swing state voters preferred the disloyal Republican to the loyal Republican. This offers some advice to Republican candidates — while they may have little hope of shifting allegiances for most voters, swing state voters and independent voters may shift their vote preferences based on the candidate's positioning on Trump.

Still, we should not be surprised by the results on the question of vote preference-it would be incredibly difficult to get a Democrat or liberal to select a Republican candidate, especially when there is the option of selecting an ideologically incongruent to Trump Democrat. As with the ambiguous candidate though, the disloyal Republican may not need to fear retribution from voters for taking this position. Indeed, none of the groups examined preferred the disloyal Republican less than their counterparts who were exposed to the loyal Republican. What may provide a better answer as to what effect these positions are taking is the overall thermometer score that participants gave the candidates. Table 4 summarizes the difference between the participants in the loyal group and the ambiguous group.

[Insert Table 4 here]

Again, we see few significant differences between the participants assigned to the loyal group and the ambiguous group. There were no significant differences between the loyal and ambiguous group participants by party identification, ideology, or the type of state that they reside in. Clinton voters did give a higher average thermometer rating for the ambiguous Republican than the loyal Republican. Still, the change was less than five degrees and the end result was still only an average thermometer rating of 21.94 -well under the neutral score of "50." All this seems to suggest that voters do not view the ambiguous option as a viable means 
for a candidate to distance herself from Trump. Still, while it may not accomplish the desired effects, it does not seem to damage the candidate either.

Turning again to the differences between the loyal and disloyal Republicans, the differences are starker.

\section{[Insert Table 5 here]}

Looking at partisan affiliations, Democrats who were exposed to the disloyal Republican gave a thermometer score that was nearly seven points higher than did the Democrats who were exposed to the loyal Republican. Similarly, liberals in the disloyal group also rated their Republican higher than liberals in the loyal group by nearly the same margin (6.33 points higher in this case). Still, while the differences here are relatively large, the value that Democrats and liberals give to the disloyal Republican is not encouraging for the strategy. Indeed, Democrats scored the disloyal Republican at an average score of 24.79 while liberals scored the disloyal Republican at an average score of 24.74 , well below the neutral score of " 50 ," suggesting that while the disloyal Republican is preferred to the loyal Republican, the difference does not yield electoral benefits.

There is one interesting finding that could suggest electoral benefits for some Republicans, however. Swing state voters in the disloyal group rated their Republican 9.31 degrees higher than swing state voters in the loyal group. Perhaps more importantly, the average rating for the disloyal Republican was 42.79 . This seems to be driven by independents in swing states who rated the disloyal Republican nearly 13 points higher than independents in swing states rated the loyal Republican. While this value is still relatively low, it does suggest that swing state voters can be moved to become more amenable to the Republican candidate. 
As mentioned earlier, the excitement to vote for a candidate can provide a proxy for turnout, a crucial aspect of electoral outcomes. Table Six describes the differences in the average excitement to vote for the Republican candidate for the loyal and ambiguous groups.

[Insert Table 6 here]

As with the previous analyses between these two groups, there are few significant differences between the loyal and ambiguous groups. Indeed the only difference that is statistically worth mentioning is amongst Clinton voters. Clinton voters in the ambiguous group were on average .41 points more excited than Clinton voters in the loyal group to vote for the Republican candidate. Still, the overall value was 1.38 suggesting little evidence that Clinton voters would have turned out for the ambiguous Republican (The rating is based on a scale from 0-10). There were, however, more differences in strength and quantity between the loyal and disloyal groups. Table Seven lists these differences.

[Insert Table 7 here]

In terms of partisanship, only Democrats showed any difference between the loyal and disloyal Republicans in that Democrats exposed to the disloyal Republican expressed an average excitement score that was .63 points higher than Democrats exposed to the loyal Republican. Similarly, liberals in the disloyal group also expressed a higher excitement score on average than liberals in the loyal group by a margin of .35 points. Still, perhaps most interestingly, conservatives in the disloyal group also expressed a higher excitement score to vote for the Republican than conservatives in the loyal group by a margin of .71 points.

Even still, swing state voters demonstrated the largest difference as swing state voters were 1.13 points more excited to vote for the Republican in the disloyal group than swing state voters in the loyal group. While the value remains relatively low at 3.59 , such a seismic shift 
suggests potential that the Republican candidate can gain ground with voters in swing states. Again, it seems that independents and Republicans are driving this in swing states as each group rated the disloyal Republican higher than their counterparts did the loyal Republican (1.49 and 1.43, respectively). Most importantly for the candidate, the strategy does not seem to have a downside as no group "punished" the Republican for taking the disloyal position to Trump.

\section{Conclusion}

In this paper, we have sought to offer an early analysis on how candidates can use positioning to distance himself or herself from an unpopular presidential candidate. While we find that neither ambiguity nor outright disloyalty work to distance the candidate completely from the presidential candidate, they do yield positive effects.

The ambiguity strategy is the weakest alternative to the loyal strategy, though it does

yield some positive differences. Specifically, independents preferred the ambiguous Republican slightly to the loyal Republican in terms of candidate preference, as did liberals. The disloyal strategy was most effective amongst swing state voters, an effect that is likely being driven by independents and Republicans in these states who prefer a candidate that is willing to stand up to unpopular candidate given the unique ideological status of their state. Perhaps most important amongst all of this is that the strategy did not backfire significantly with any major group. That is, in terms of partisanship, ideology, and the type of state the participants resided in, no major group preferred the loyal Republican to the ambiguous or disloyal Republican with regards to preference, thermometer score, or excitement to vote for the candidate.

Indeed, even looking forward, the mix of 2018 Republican senators that were once favored for reelection are publically struggling to respond appropriately to Trump. Some 
such as Senator Jeff Flake of Arizona have decided to openly repudiate the words and actions of the President. In his 2017 book, The Conscience of a Conservative, he described Trump's actions as, "Reckless, outrageous, and undignified behavior has become excused and countenanced as telling it like it is when it is actually just reckless, outrageous, and undignified. And when such behavior emanates from the top of our government, it is something else. It is dangerous to a democracy." Flake has since declared that he is not seeking reelection.

Some like Alabama senate Republican candidate Roy Moore decided to pledge their undivided loyalty to Trump. Moore would continually talk about his affinity to Trump and how he would go to Washington D.C. to fight for Trump's agenda. In fact, a personal run-in with President Trump on Obamacare repeal convinced Nevada Senator Dean Heller to play the quiet game by avoiding the media and refusing to weigh in on Trump. The wide variation in response to Trump, however, suggests politicians have no idea which of the three strategies are optimal. 
Tables

Table 1: Description of Distribution of Socio-Political Variables

\begin{tabular}{l|c|c|c}
\hline \multicolumn{4}{c}{ Description of Variables } \\
\hline Percent Male & Trump Ambiguous & Trump Disloyal & Trump Loyal \\
\hline Percent White & 43.04 & 43.1 & 42.65 \\
\hline Percent Black & 76.81 & 78.37 & 77.54 \\
\hline Percent Hispanic & 7.66 & 8.57 & 9.22 \\
\hline Percent Asian Am & 6.42 & 5.78 & 5.44 \\
\hline Percent Republican & 7.25 & 5.57 & 6.15 \\
\hline Percent Democrat & 23.41 & 25.5 & 22.25 \\
\hline Percent Independent & 39.61 & 43.4 & 42.05 \\
\hline Percent Conservative & 33.92 & 28.41 & 32.52 \\
\hline Percent Liberal & 29.65 & 30.31 & 26.34 \\
\hline Percent Moderate & 44.59 & 49.34 & 48.54 \\
\hline Percent Swing State & 25.76 & 20.35 & 25.12 \\
\hline Percent Red State & 26.29 & 24.2 & 25.53 \\
\hline Percent Blue State & 36.02 & 41.76 & 41.61 \\
\hline
\end{tabular}


Table 2:

\begin{tabular}{|c|c|c|c|c|}
\hline \multicolumn{5}{|c|}{$\begin{array}{l}\text { Differences between Embrace and Ambiguous Groups For Average Candidate Preference } \\
\text { Numbers Represent Percent of Participants Preferring Republican in Each Group }\end{array}$} \\
\hline & $\begin{array}{l}\text { "Embrace" } \\
\text { Group Value }\end{array}$ & $\begin{array}{l}\text { "Ambiguous" Group } \\
\text { Value }\end{array}$ & Difference & $\begin{array}{c}\text { Number of } \\
\text { Observations } \\
\text { (Embrace, Ambiguous) }\end{array}$ \\
\hline \multicolumn{5}{|l|}{ Party ID } \\
\hline Democrat & 1.16 & 3.31 & .2 .15 & $(172,181)$ \\
\hline Independent & 32.33 & 41.94 & $9.61 *$ & $(133,155)$ \\
\hline Republican & 85.71 & 91.59 & 5.98 & $(91,107)$ \\
\hline \multicolumn{5}{|l|}{ Ideology } \\
\hline Liberal & 2.51 & 6.31 & $3.8^{*}$ & $(199,206)$ \\
\hline Moderate & 34.95 & 40.38 & 5.43 & $(103,119)$ \\
\hline Conservative & 80.56 & 84.67 & 4.11 & $(108,137)$ \\
\hline \multicolumn{5}{|l|}{ Type of State } \\
\hline Red State & 33.90 & 44.35 & $10.45 *$ & $(118,124)$ \\
\hline Blue State & 28.78 & 36.96 & 8.18 & $(139,184)$ \\
\hline Swing State & 31.48 & 37.01 & 5.53 & $(108,127)$ \\
\hline \multicolumn{5}{|l|}{2016 Vote Choice } \\
\hline Trump Voters & 87.63 & 95.97 & $8.34 * *$ & $(97,124)$ \\
\hline Clinton Voters & 3.59 & 5.00 & 1.31 & $(167,180)$ \\
\hline
\end{tabular}

$* \mathrm{P}<.1, * * \mathrm{P}<.05, * * * \mathrm{P}<.01$ 
Table 3:

Differences between Embrace and Eschew Groups For Average Candidate Preference Numbers Represent Percent of Participants Preferring Republican in Each Group

\begin{tabular}{|c|c|c|c|c|}
\hline & $\begin{array}{l}\text { "Embrace" } \\
\text { Group Value }\end{array}$ & "Eschew" Group Value & Difference & $\begin{array}{c}\text { Number of } \\
\text { Observations } \\
\text { (Embrace, Eschew) }\end{array}$ \\
\hline \multicolumn{5}{|l|}{ Party ID } \\
\hline Democrat & 1.16 & 3.61 & 2.45 & $(172,194)$ \\
\hline Independent & 32.33 & 33.86 & 1.53 & $(133,127)$ \\
\hline Republican & 85.71 & 89.47 & 3.76 & $(91,114)$ \\
\hline \multicolumn{5}{|l|}{ Ideology } \\
\hline Liberal & 2.51 & 4.04 & 1.53 & $(199,223)$ \\
\hline Moderate & 34.95 & 40.22 & 5.27 & $(103,92)$ \\
\hline Conservative & 80.56 & 80.29 & -.27 & $(108,137)$ \\
\hline \multicolumn{5}{|l|}{ Type of State } \\
\hline Red State & 33.90 & 35.20 & 1.3 & $(118,125)$ \\
\hline Blue State & 28.78 & 25.93 & -2.85 & $(139,162)$ \\
\hline Swing State & 31.48 & 45.13 & $13.65^{* *}$ & $(108,113)$ \\
\hline \multicolumn{5}{|l|}{2016 Vote Choice } \\
\hline Trump Voters & 87.63 & 94.83 & $7.2^{*}$ & $(97,116)$ \\
\hline Clinton Voters & 3.59 & 4.62 & 1.03 & $(167,195)$ \\
\hline
\end{tabular}

$* \mathrm{P}<.1, * * \mathrm{P}<.05, * * * \mathrm{P}<.01$ 
Table 4:

Differences between Embrace and Ambiguous Groups For Average Thermometer Score

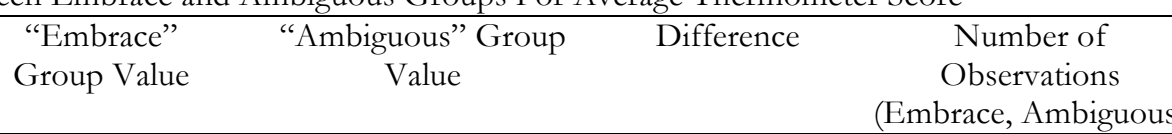

\begin{tabular}{lcccc}
\hline Party ID & & & & \\
Democrat & 17.91 & 20.55 & 2.64 & $(172,181)$ \\
Independent & 31.87 & 34.34 & 2.47 & $(133,155)$ \\
Republican & 70.04 & 69.00 & -1.04 & $(91,107)$ \\
Ideology & & & & $(199,206)$ \\
Liberal & 18.39 & 20.05 & 1.66 & $(103,119)$ \\
Moderate & 36.76 & 36.84 & .08 & $(108,137)$ \\
Conservative & 60.63 & 61.56 & .93 & $(118,124)$ \\
Type of State & & & 5.65 & $(139,184)$ \\
Red State & 35.60 & 41.25 & -.64 & $(108,127)$ \\
Blue State & 34.91 & 34.27 & 4.02 & $(97,124)$ \\
Swing State & 33.48 & 37.50 & & $(167,180)$ \\
2016 Vote Choice & & & 4.53 & \\
Trump Voters & 70.15 & 65.62 & $4.47 * *$ & \\
Clinton Voters & 17.46 & 21.94 & & \\
\hline
\end{tabular}

$* \mathrm{P}<.1, * * \mathrm{P}<.05, * * * \mathrm{P}<.01$ 
Table 5:

Differences between Embrace and Eschew Groups For Average Thermometer Score

$\begin{array}{lll}\text { "Embrace" "Eschew" Group Value Difference } & \text { Number of } \\ \text { Group Value } & \text { Observations }\end{array}$

(Embrace, Eschew)

\begin{tabular}{|c|c|c|c|c|}
\hline \multicolumn{5}{|l|}{ Party ID } \\
\hline Democrat & 17.91 & 24.79 & $6.88^{* * *}$ & $(172,194)$ \\
\hline Independent & 31.88 & 33.61 & 1.73 & $(133,127)$ \\
\hline Republican & 70.04 & 71.82 & 1.78 & $(91,114)$ \\
\hline \multicolumn{5}{|l|}{ Ideology } \\
\hline Liberal & 18.39 & 24.74 & $6.35^{* * *}$ & $(199,233)$ \\
\hline Moderate & 36.76 & 37.53 & .77 & $(103,92)$ \\
\hline Conservative & 60.63 & 63.52 & 2.89 & $(108,137)$ \\
\hline \multicolumn{5}{|l|}{ Type of State } \\
\hline Red State & 35.60 & 41.86 & 6.26 & $(118,125)$ \\
\hline Blue State & 34.91 & 34.95 & .04 & $(139,162)$ \\
\hline Swing State & 33.48 & 42.79 & $9.31 * *$ & $(108,113)$ \\
\hline \multicolumn{5}{|l|}{2016 Vote Choice } \\
\hline Trump Voters & 70.15 & 70.82 & .67 & $(97,116)$ \\
\hline Clinton Voters & 17.46 & 26.39 & $8.93 * * *$ & $(167,195)$ \\
\hline
\end{tabular}

$* \mathrm{P}<.1, * * \mathrm{P}<.05, * * * \mathrm{P}<.01$ 
Table 6:

Differences between Embrace and Ambiguous Groups For Average Excitement Score

\begin{tabular}{|c|c|c|}
\hline "Embrace" & "Ambiguous" Group & Difference \\
\hline
\end{tabular}

(Embrace, Ambiguous)

Party ID

Democrat

.98

Independent

2.30

.22

Republican

6.21

2.43

.13

.1

$(172,181)$

Ideology

Liberal

1.13

2.86

1.15

.02

Moderate

5.05

2.59

$-.27$

Conservative

5.37

.32

$(133,155)$

Type of State

Red State

2.89

Blue State

2.59

3.36

.47

2.5

2.46

2.80

$-.09$

2016 Vote Choice

Trump Voters

6.41

6.24

.34

$(91,107)$

Clinton Voters

.97

1.38

.17

$.41 * *$

$(199,206)$

$(103,119)$

$(108,137)$

$* \mathrm{P}<.1, * * \mathrm{P}<.05, * * * \mathrm{P}<.01$ 
Table 7:

\begin{tabular}{|c|c|c|c|c|}
\hline \multicolumn{5}{|c|}{ Differences between Embrace and Eschew Groups For Average Excitement Score } \\
\hline & $\begin{array}{l}\text { "Embrace" } \\
\text { Group Value }\end{array}$ & "Eschew" Group Value & Difference & $\begin{array}{c}\text { Number of } \\
\text { Observations } \\
\text { (Embrace, Eschew) }\end{array}$ \\
\hline \multicolumn{5}{|l|}{ Party ID } \\
\hline Democrat & .98 & 1.61 & $.63^{* * *}$ & $(172,194)$ \\
\hline Independent & 2.30 & 2.47 & .17 & $(133,127)$ \\
\hline Republican & 6.21 & 6.57 & .37 & $(91,114)$ \\
\hline \multicolumn{5}{|l|}{ Ideology } \\
\hline Liberal & 1.13 & 1.48 & $.35^{*}$ & $(199,233)$ \\
\hline Moderate & 2.86 & 2.97 & .11 & $(103,92)$ \\
\hline Conservative & 5.05 & 5.76 & $.71 *$ & $(108,137)$ \\
\hline \multicolumn{5}{|l|}{ Type of State } \\
\hline Red State & 2.89 & 3.28 & .39 & $(118,125)$ \\
\hline Blue State & 2.59 & 2.60 & .01 & $(139,162)$ \\
\hline Swing State & 2.46 & 3.59 & $1.13^{* * *}$ & $(108,113)$ \\
\hline \multicolumn{5}{|l|}{2016 Vote Choice } \\
\hline Trump Voters & 6.41 & 6.72 & .31 & $(97,116)$ \\
\hline Clinton Voters & .97 & 1.65 & $.68^{* * *}$ & $(167,195)$ \\
\hline
\end{tabular}




\section{Appendix A}

\begin{tabular}{ll}
\hline & Appendix B: Typology of States \\
\hline Blue States & CA, CT, DE, HI, IL, NJ, NM, NY,MA, MI, \\
& MN, OR, RI, VT, WA, WI \\
\hline Red States & AL, AK, AR, AZ, GA, ID, IN, KS, KY, LA, \\
& MS, MO, MT, NV, SC, SD, TN, TX, UT, WV, \\
\hline Swing States & WY \\
\hline
\end{tabular}




\section{Appendix B}

\begin{tabular}{|c|c|c|c|c|}
\hline \multicolumn{5}{|c|}{$\begin{array}{l}\text { Differences between Embrace and Ambiguous Groups For Average Candidate Preference } \\
\text { Numbers Represent Percent of Participants Preferring Republican in Each Group }\end{array}$} \\
\hline & $\begin{array}{l}\text { "Embrace" } \\
\text { Group Value }\end{array}$ & $\begin{array}{l}\text { "Ambiguous" Group } \\
\text { Value }\end{array}$ & Difference & $\begin{array}{c}\text { Number of } \\
\text { Observations } \\
\text { (Embrace, Ambiguous) }\end{array}$ \\
\hline \multicolumn{5}{|l|}{ Interactions } \\
\hline Democrats in Red States & 2.27 & 4.76 & 2.49 & $(44,42)$ \\
\hline Independents in Red States & 34.15 & 31.25 & -2.9 & $(41,32)$ \\
\hline Republicans in Red States & 88.46 & 97.37 & 8.91 & $(26,38)$ \\
\hline Liberals in Red States & 1.96 & 7.41 & 5.45 & $(51,54)$ \\
\hline Moderates in Red States & 41.38 & 42.86 & 1.48 & $(29,21)$ \\
\hline Conservatives in Red States & 84.38 & 90.91 & 6.53 & $(32,44)$ \\
\hline Democrats in Swing States & 0.00 & 4.17 & 4.17 & $(43,48)$ \\
\hline Independents in Swing States & 30.30 & 37.21 & 6.91 & $(33,43)$ \\
\hline Republicans in Swing States & 81.48 & 90.0 & 8.52 & $(27,30)$ \\
\hline Liberals in Swing States & 1.85 & 5.88 & 4.03 & $(54,51)$ \\
\hline Moderates in Swing States & 45.45 & 43.90 & -1.55 & $(22,41)$ \\
\hline Conservatives in Swing States & 76.67 & 78.57 & 1.9 & $(30,28)$ \\
\hline Democrats in Blue States & 0.00 & 2.94 & 2.94 & $(59,68)$ \\
\hline Independents in Blue States & 37.21 & 48.48 & 11.27 & $(43,66)$ \\
\hline Republicans in Blue States & 88.89 & 84.85 & -4.04 & $(27,33)$ \\
\hline Liberals in Blue States & 3.12 & 5.33 & 2.21 & $(64,75)$ \\
\hline Moderates in Blue States & 31.71 & 39.22 & 7.51 & $(41,51)$ \\
\hline Conservatives in Blue States & 77.42 & 79.63 & 2.21 & $(31,54)$ \\
\hline
\end{tabular}

$* \mathrm{P}<.1, * * \mathrm{P}<.05, * * * \mathrm{P}<.01$ 


\section{Appendix C}

\begin{tabular}{lcccc}
\hline \multicolumn{4}{c}{$\begin{array}{c}\text { Differences between Embrace and Eschew Groups For Average Candidate Preference } \\
\text { Numbers Represent Percent of Participants Preferring Republican in Each Group }\end{array}$} \\
\hline & $\begin{array}{c}\text { "Embrace" } \\
\text { Group Value }\end{array}$ & $\begin{array}{c}\text { "Eschew" } \\
\text { Group Value }\end{array}$ & Difference & $\begin{array}{c}\text { Number of } \\
\text { Observations } \\
\text { (Embrace, Ambiguous) }\end{array}$ \\
\cline { 2 - 5 } Interactions & & & \\
Democrats in Red States & 2.27 & 3.92 & 1.65 & $(44,51)$ \\
Independents in Red States & 34.15 & 34.38 & .23 & $(41,32)$ \\
Republicans in Red States & 88.46 & 84.85 & -3.61 & $(26,33)$ \\
Liberals in Red States & 1.96 & 1.82 & -.14 & $(51,55)$ \\
Moderates in Red States & 41.38 & 33.33 & -8.05 & $(29,24)$ \\
Conservatives in Red States & 84.38 & 82.50 & -1.88 & $(32,40)$ \\
Democrats in Swing States & 0.00 & 2.13 & 2.13 & $(43,47)$ \\
Independents in Swing States & 30.30 & 62.96 & $32.66^{* *}$ & $(33,27)$ \\
Republicans in Swing States & 81.48 & 100.0 & $18.52^{* *}$ & $(27,32)$ \\
Liberals in Swing States & 1.85 & 6.12 & 4.27 & $(54,49)$ \\
Moderates in Swing States & 45.45 & 55.00 & 9.55 & $(22,20)$ \\
Conservatives in Swing States & 76.67 & 91.89 & $15.22 *$ & $(30,37)$ \\
Democrats in Blue States & 0.00 & 2.86 & 2.86 & $(59,70)$ \\
Independents in Blue States & 37.21 & 18.37 & $-18.84 *$ & $(43,49)$ \\
Republicans in Blue States & 88.89 & 83.87 & -5.02 & $(27,31)$ \\
Liberals in Blue States & 3.12 & 4.35 & 1.23 & $(64,92)$ \\
Moderates in Blue States & 31.71 & 34.48 & 2.77 & $(41,29)$ \\
Conservatives in Blue States & 77.42 & 70.00 & -7.42 & $(31,40)$ \\
\hline
\end{tabular}

*P $<.1,{ }^{*} * \mathrm{P}<.05,{ }^{* * *} \mathrm{P}<.01$ 


\section{Appendix D}

\begin{tabular}{lcccc}
\hline \multicolumn{4}{c}{ Differences between Embrace and Ambiguous Groups For Average Thermometer Score } \\
\hline & $\begin{array}{c}\text { "Embrace" } \\
\text { Group Value }\end{array}$ & $\begin{array}{c}\text { "Ambiguous" Group } \\
\text { Value }\end{array}$ & Difference & $\begin{array}{c}\text { Number of } \\
\text { Observations } \\
\text { (Embrace, Ambiguous) }\end{array}$ \\
\cline { 2 - 5 } $\begin{array}{l}\text { Interactions } \\
\text { Democrats in Red States }\end{array}$ & 18.89 & 24.71 & 5.82 & $(44,42)$ \\
Independents in Red States & 31.27 & 33.66 & 2.39 & $(41,32)$ \\
Republicans in Red States & 67.62 & 66.55 & -1.07 & $(26,38)$ \\
Liberals in Red States & 20.88 & 24.57 & 3.69 & $(51,54)$ \\
Moderates in Red States & 29.79 & 40.38 & 10.59 & $(29,21)$ \\
Conservatives in Red States & 60.38 & 61.70 & 1.32 & $(32,44)$ \\
Democrats in Swing States & 17.72 & 18.77 & 1.05 & $(43,48)$ \\
Independents in Swing States & 26.94 & 32.86 & 5.92 & $(33,43)$ \\
Republicans in Swing States & 66.14 & 74.20 & 8.06 & $(27,30)$ \\
Liberals in Swing States & 18.39 & 16.14 & -2.25 & $(54,51)$ \\
Moderates in Swing States & 42.00 & 44.22 & 2.22 & $(22,41)$ \\
Conservatives in Swing States & 56.63 & 62.82 & 6.18 & $(30,28)$ \\
Democrats in Blue States & 16.71 & 20.21 & 3.50 & $(59,68)$ \\
Independents in Blue States & 36.70 & 33.98 & -2.72 & $(43,66)$ \\
Republicans in Blue States & 77.07 & 66.45 & $-10.62 *$ & $(27,33)$ \\
Liberals in Blue States & 16.95 & 19.16 & 2.21 & $(41,55)$ \\
Moderates in Blue States & 40.00 & 29.69 & $-10.31 * *$ & $(31,54)$ \\
Conservatives in Blue States & 65.06 & 59.87 & -5.19 & \\
\hline
\end{tabular}

\footnotetext{
* $\mathrm{P}<.1,{ }^{* *} \mathrm{P}<.05,{ }^{* * *} \mathrm{P}<.01$
} 
Appendix E

\begin{tabular}{|c|c|c|c|c|}
\hline \multicolumn{5}{|c|}{ Differences between Embrace and Eschew Groups For Average Thermometer Score } \\
\hline & $\begin{array}{l}\text { "Embrace" } \\
\text { Group Value }\end{array}$ & "Eschew" Group Value & Difference & $\begin{array}{c}\text { Number of } \\
\text { Observations } \\
\text { (Embrace, Ambiguous) }\end{array}$ \\
\hline \multicolumn{5}{|l|}{ Interactions } \\
\hline Democrats in Red States & 18.89 & 25.78 & 6.89 & $(44,51)$ \\
\hline Independents in Red States & 41.27 & 40.56 & 9.29 & $(41,32)$ \\
\hline Republicans in Red States & 67.62 & 73.18 & 5.56 & $(26,33)$ \\
\hline Liberals in Red States & 20.88 & 28.00 & $7.12^{*}$ & $(51,55)$ \\
\hline Moderates in Red States & 29.79 & 33.29 & 3.50 & $(29,34)$ \\
\hline Conservatives in Red States & 60.38 & 67.88 & 7.5 & $(32,40)$ \\
\hline Democrats in Swing States & 17.72 & 23.19 & 5.47 & $(43,47)$ \\
\hline Independents in Swing States & 26.94 & 39.56 & $12.62^{*}$ & $(33,27)$ \\
\hline Republicans in Swing States & 66.15 & 72.5 & 6.35 & $(27,32)$ \\
\hline Liberals in Swing States & 18.39 & 24.94 & 6.54 & $(54,49)$ \\
\hline Moderates in Swing States & 42.00 & 47.05 & 5.05 & $(22,20)$ \\
\hline Conservatives in Swing States & 56.63 & 61.68 & 5.05 & $(30,37)$ \\
\hline Democrats in Blue States & 16.71 & 23.67 & $6.96 *$ & $(59,70)$ \\
\hline Independents in Blue States & 36.70 & 27.12 & $-9.58^{*}$ & $(43,49)$ \\
\hline Republicans in Blue States & 77.07 & 73.29 & -3.78 & $(27,31)$ \\
\hline Liberals in Blue States & 16.95 & 22.18 & 5.23 & $(64,92)$ \\
\hline Moderates in Blue States & 40 & 37.03 & -2.97 & $(41,29)$ \\
\hline Conservatives in Blue States & 65.06 & 62.43 & -2.63 & $(31,40)$ \\
\hline
\end{tabular}

* $\mathrm{P}<.1,{ }^{* *} \mathrm{P}<.05,{ }^{* * *} \mathrm{P}<.01$ 


\section{Appendix F}

\begin{tabular}{|c|c|c|c|c|}
\hline \multicolumn{5}{|c|}{ Differences between Embrace and Eschew Groups For Average Excitement Score } \\
\hline & $\begin{array}{l}\text { "Embrace" } \\
\text { Group Value }\end{array}$ & $\begin{array}{c}\text { "Ambiguous" Group } \\
\text { Value }\end{array}$ & Difference & $\begin{array}{c}\text { Number of } \\
\text { Observations } \\
\text { (Embrace, Eschew) }\end{array}$ \\
\hline \multicolumn{5}{|l|}{ Interactions } \\
\hline Democrats in Red States & 1.14 & 1.57 & .43 & $(44,42)$ \\
\hline Independents in Red States & 2.49 & 2.40 & -.09 & $(41,32)$ \\
\hline Republicans in Red States & 6.08 & 6.29 & .21 & $(26,38)$ \\
\hline Liberals in Red States & 1.31 & 1.52 & .21 & $(51,54)$ \\
\hline Moderates in Red States & 2.62 & 3.38 & .76 & $(29,21)$ \\
\hline Conservatives in Red States & 5.34 & 5.61 & .27 & $(32,44)$ \\
\hline Democrats in Swing States & .98 & 1.08 & .1 & $(43,48)$ \\
\hline Independents in Swing States & 1.70 & 2.26 & .56 & $(33,43)$ \\
\hline Republicans in Swing States & 5.85 & 6.5 & .65 & $(27,30)$ \\
\hline Liberals in Swing States & 1.15 & .90 & -.25 & $(54,51)$ \\
\hline Moderates in Swing States & 3.45 & 3.02 & -.43 & $(22,41)$ \\
\hline Conservatives in Swing States & 4.27 & 5.43 & 1.16 & $(30,28)$ \\
\hline Democrats in Blue States & .88 & 1.18 & .30 & $(59,68)$ \\
\hline Independents in Blue States & 2.74 & 2.45 & -.29 & $(43,66)$ \\
\hline Republicans in Blue States & 6.70 & 6.00 & -.7 & $(27,33)$ \\
\hline Liberals in Blue States & 1.06 & 1.00 & -.06 & $(64,75)$ \\
\hline Moderates in Blue States & 2.88 & 1.94 & $-.94 *$ & $(41,51)$ \\
\hline Conservatives in Blue States & 5.58 & 5.19 & -.39 & $(31,54)$ \\
\hline
\end{tabular}

$\mathrm{P}<.1, * * \mathrm{P}<.05, * * * \mathrm{P}<.01$ 


\section{Appendix G}

\begin{tabular}{|c|c|c|c|c|}
\hline \multicolumn{5}{|c|}{ Differences between Embrace and Eschew Groups For Average Excitement Score } \\
\hline & $\begin{array}{l}\text { "Embrace" } \\
\text { Group Value }\end{array}$ & "Eschew" Group Value & Difference & $\begin{array}{c}\text { Number of } \\
\text { Observations } \\
\text { (Embrace, Eschew) }\end{array}$ \\
\hline \multicolumn{5}{|l|}{ Interactions } \\
\hline Democrats in Red States & 1.14 & 1.76 & $.62 *$ & $(44,51)$ \\
\hline Independents in Red States & 2.49 & 2.75 & .26 & $(41,32)$ \\
\hline Republicans in Red States & 6.08 & 6.60 & .52 & $(26,33)$ \\
\hline Liberals in Red States & 1.31 & 1.60 & .29 & $(51,55)$ \\
\hline Moderates in Red States & 2.62 & 2.58 & -.04 & $(29,24)$ \\
\hline Conservatives in Red States & 5.34 & 6.18 & .84 & $(32,40)$ \\
\hline Democrats in Swing States & .98 & 1.53 & .55 & $(43,47)$ \\
\hline Independents in Swing States & 1.70 & 3.19 & $1.49^{* *}$ & $(33,27)$ \\
\hline Republicans in Swing States & 5.85 & 7.28 & $1.43^{*}$ & $(27,32)$ \\
\hline Liberals in Swing States & 1.15 & 1.51 & .36 & $(54,49)$ \\
\hline Moderates in Swing States & 3.45 & 4.05 & .60 & $(22,20$ \\
\hline Conservatives in Swing States & 4.27 & 6.19 & $1.92 * *$ & $(30,37)$ \\
\hline Democrats in Blue States & .88 & 1.43 & $.55^{*}$ & $(59,70)$ \\
\hline Independents in Blue States & 2.74 & 2.04 & -.70 & $(43,49)$ \\
\hline Republicans in Blue States & 6.70 & 6.42 & -.28 & $(27,31)$ \\
\hline Liberals in Blue States & 1.06 & 1.34 & .28 & $(64,92)$ \\
\hline Moderates in Blue States & 2.88 & 2.93 & .05 & $(41,29)$ \\
\hline Conservatives in Blue States & 5.58 & 5.30 & -.28 & $(31,40)$ \\
\hline
\end{tabular}

$\mathrm{P}<.1,{ }^{* *} \mathrm{P}<.05,{ }^{* * *} \mathrm{P}<.01$ 


\section{References}

Abramowitz, Alan. "National Issues, Strategic Politicians, and Voting Behavior in the 1980 and 1982 Congressional Elections.” American Journal of Political Science (1984): 710-721.

---. "Economic Conditions, Presidential Popularity, and Voting Behavior in Midterm

Congressional Elections." The Journal of Politics 47:1 (1985): 31-43.

Abramowitz, Alan and Jeffrey Allan Segal. Senate Elections. Ann Arbor: University of Michigan Press, 1992.

Adams, James, Benjamin G. Bishin and Jay K. Dow. "Representation in Congressional Campaigns: Evidence for Discounting/Directional Voting in the U.S. Senate Elections." Journal of Politics 66 (2004): 348-73.

Brady, David W., John F. Cogan, Brian J. Gaines, and Douglas Rivers. "the Perils of Presidential Support: How the Republicans Took the House in the 1994 Midterm Elections." Political Behavior 18 (1996): 345-367.

Brady, David W., Brandice Canes-Wrone, and John F. Cogan. "Differences in legislative voting behavior between winning and losing House incumbents." Continuity and change in House Elections (2000): 149-177.

Campbell, James. "The Electoral Consequences of Issue Ambiguity: An Examination of the Presidential Candidates' Issue Positions from 1968 to 1980.” Political Behavior 5:3 (1983): 277291.

Campbell, James and Joe Sumners. "Presidential Coattails in Senate Elections," The American Political Science Review 84:2 (1990): 513-524.

Chaturvedi, Neilan S. "Kings of the Hill: An Examination of Centrist Behavior in the United States Senate.” Social Science Quarterly (2017) forthcoming. doi:10.1111/ssqu. 12362.

Cover, Albert D. "Presidential Evaluations and Voting for Congress." The American Journal of Political Science 30 (1986): 786-801.

Downs, Anthony. "An economic theory of political action in a democracy." The journal of political economy (1957): 135-150.

Fiorina, Morris P. Divided Government. New York: Macmillan, 1992.

Grofman, Bernard. "The Neglected Role of the Status Quo in Models of Issue Voting." Journal of Politics 47 (1985): 230-237.

Gronke, Paul, Jeffrey Koch, and J. Matthew Wilson. "Follow the Leader? Presidential Approval, Presidential Support, and Representatives' Electoral Fortunes," The Journal of Politics 65:3 (2003): 785-808. 
Grose, Christian, Neil Malhotra, and Robert Parks Van Houweling. "Explaining Explanations: How Legislators Explain their Policy Positions and How Citizens React." American Journal of Political Science 59:3 (2014): 724-743.

Hibbing, John R. and John R. Alford. "The Electoral Impact of Economic Conditions: Who is Held Responsible?” American Journal of Political Science 25:3 (1981): 423-439.

Irwin, Francis. "States Expectations as Functions of Probability and Desirability of Outcomes." Journal of Personality 21:3 (1953): 329-35.

Jacobson, Gary C. "Campaign Spending Effects in US Senate Elections: Evidence from the National Annenberg Election Survey.” Electoral Studies 25(2): (2006): 195-226.

---. "Reversal of Fortune: The Transformation of US House Elections in the 1990s." Legislative Studies Quarterly 22:4 (1997): 586-596.

Kernell, Samuel. "Presidential Popularity and Negative Wording." American Political Science Review 71 (1977): 44-66.

Krosnick, Jon A. "The Challenges of Political Psychology: Lessons to be Learned from Research on Attitude Perception.” In Thinking about Political Psychology ed. James H. Kuklinski. New York: Cambridge University Press, 2002.

Rabinowitz, George and Stuart Elaine Macdonald. "A Directional Theory of Issue Voting." American Political Science Review 83 (1989): 93-121.

Rosenhan, David and Samuel Messick. "Affect and Expectation.” Journal of Personality and Social Psychology 3:1 (1966): 38-44.

Shepsle, Kenneth A. "The Strategy of Ambiguity: Uncertainty and Electoral Competition." American Political Science Review 66:2 (1972): 555-568.

Tomz, Michael and Robert Parks Van Houweling. "Candidate Positioning and Voter Choice." The American Political Science Review 102:3 (2008): 303-318.

---. "The Electoral Implications of Candidate Ambiguity." The American Political Science Review 103:1 (2009): 83-98.

Tufte, Edward R. "Determinants of the Outcomes of Midterm Congressional Elections." American Political Science Review 69 (1975): 812-26. 